\title{
A qualitative approach for exploration of feeding practices, knowledge, and attitudes on child nutrition framework
}

\author{
Rozanne Kruger and Gerda Gericke
}

\begin{abstract}
OPSOMMING
Doel: Chroniese wanvoeding wat deur ' $\mathrm{n}$ langdurige inname van lae-kilojoule voedsels veroorsaak word, is ' $\mathrm{n}$ hardnekkige, publieke gesondheidsprobleem in meeste ontwikkelende lande soos SuidAfr-ika (SA). Kinders is die mees kwesbare groep wat hierdeur geraak word aangesien hul groei benadeel word. Voedingpraktyke in die kinderjare affekteer die voedingstatus, gesondheid en ook die groei van kinders. Hierdie navorsingsverslag bied ' $n$ oorsig van 'n kwalitatiewe benadering wat gevolg is in die ondersoek na die aard van die voeding- en speningpraktyke van moeders/versorgers van kinders 0 tot 3 jaar oud, wat die babaklinieke in twee areas in die Moretele distrik (SA) besoek. Die voedingkennis van die moeders/versorgers asook hul houdings oor kindervoeding is ook ondersoek. Die doel van hierdie artikel is om te reflekteer op die kwalitatiewe benadering en die data-analiseproses soos dit van toepassing is op voedingnavorsing.
\end{abstract}

Benadering: ' $n$ Kwalitatiewe benadering is gevolg om data oor ses relevante voedingonderwerpe te versamel deur van die fokusgroeponderhoudtegniek gebruik te maak. Onderhoude is gevoer met ' $n$ geriefsteekproef $(\mathrm{N}=174)$ van moeders/versorgers in ses ouderdomsgroepe wat saamgestel is volgens bekende dieetveranderingsfases. Opgeleide moderators (van dieselfde etnisiteit as die ondersoekgroep om kulturele-, geletterdheid- en taalprobleme te oorkom) het twee fokusgroepe per ouderdomsgroep per kliniek gevoer deur gebruik te maak van 'n getoetste, gestruktureerde onderhoudskedule. Elke fokusgroeponderhoud is op band opgeneem en direk na afloop van die onderhoud getranskribeer en vertaal. ' $n$ Vakspesialis het die transkripsies vir korrektheid en volledigheid gekontroleer. Die twee basiese benaderings vir fokusgroepdataanalise is gebruik. Inhoudsanalise het sistematiese beskrywings van die data opgelewer en etnografiese opsommings het beskrywende data verskaf.

Die ontwikkeling van die kwalitatiewe benadering insluitend die ontwerp, uitvoering en analise van die fokusgroeponderhoude word bespreek. Maatreëls wat toegepas is om geldigheid en betroubaarheid te verhoog, sowel as ' $n$ model wat die datareduksieproses uitbeeld, maak deel van die bespreking uit.

\section{- Dr R Kruger}

Department of Consumer Science

University of Pretoria

- Ms Gertruida J Gericke

Division Human Nutrition

University of Pretoria

\section{INTRODUCTION}

The widespread occurrence of chronic malnutrition in developing countries such as South Africa has been reported (Patel \& Pettifor, 1992; Ocloo, 1993). Childhood feeding practices affect the nutritional status, health and growth of children (Steyn et al, 1993). The younger children (under the age of five years) in any community are the worst victims of protein-energy malnutrition (PEM), because of their vulnerability by being in the growth phase (Ocloo, 1993).

The research of Steyn et al (1993) shows that the nutrition problem found in black preschool children is one of chronic malnutrition, caused by following a diet low in kilojoules over a long period of time (Patel \& Pettifor, 1992). Many interrelated factors contribute to this state, but the main causes appear to be the food shortage and imbalances in the diets of these children (Ocloo, 1993). Research on infant feeding (Ng'andu \& Watts, 1990; Patel \& Pettifor, 1992; Steyn et al, 1993) indicates that nutrition problems occur when breastfeeding declines with the onset of weaning, or when breastfeeding is completely terminated, or if the mother returns to the workplace, or if the weaning period lasts too long and the child's nutrient intake mainly consists of an inadequate volume of breast milk without adequate weaning (solid) foods ( $\mathrm{Ng}$ 'andu \& Watts, 1990; Prentice, 1991). Poor weaning practices can lead to stunted growth, delayed motor and mental development, immune incompetence, frequent attacks of diarrhoeal disease, PEM, micronutrient deficiencies, and most importantly, interfering with the realization of full human potential (Kibel \& Wagstaff, 1995:96; Hendricks \& Badruddin, 1992; Martorell, 1993). To alleviate or solve a community nutrition problem, like chronic malnutrition, it must be ascertained which factors in the community are causing the nutrition problem (Terry, 1993:10). The present research was undertaken during 1996 to obtain baseline descriptive data on the nutritional practices of a community where no such information was available.

In this research, a qualitative approach was followed in the exploration of the nature (not quantitative extent) of the feeding and weaning practices of the mothers/caregivers of children (aged 0-36 months) attending the baby clinics in two areas in the Moretele district (situated in the Hammanskraal area north of Pretoria). Their nutrition knowledge and attitudes towards child nutrition, the physical and food environments, as well as cultural influences formed part of the exploration. The qualitative approach and subsequent methodology used will be discussed. Ethical approval was obtained from the Ethics \& Protocol Committee of the Faculty of Health Sciences, University of Pretoria. 


\section{RESEARCH PERSPECTIVE}

This exploration can be described as prospective and descriptive in the qualitative research domain. A qualitative approach favours gathering descriptive, high-quality information about the physical environment, culture, nutritional practices and food environment of the community more than a quantitative approach (Terry, 1993:17-18; Denzin \& Lincoln, 1994:343). Qualitative reports also provide access and insight into particular practices and experiences but do not try to discover relationships (Giacomini, 2001:4). Exploratory studies attempt to determine whether a phenomenon exists, in this case malnutrition among children (0 - 36 months). Descriptive studies attempt to examine a phenomenon to more fully define it, or differentiate it from others: in this case feeding practices, knowledge and attitudes about child nutrition (Denzin \& Lincoln, 1994:343-4).

This transcultural research study, where the research population belonged to a different culture to that of the researcher and the interviewer, challenged the research methodology in several aspects. Firstly, language problems were experienced, with the researcher conversing in a second language and the moderator and mothers/caregivers conversing in a second or third language. Secondly, the acceptance of the researcher belonging to a different culture and background could possibly influence veracity and completeness of data gathered. Appropriate methodology, accommodating the researcher and the respondents who belonged to different cultures, had to be developed. Schoeman (1988:2) recommends a research strategy that involves observation or dialogue of some kind, thus reducing the differences between the researcher and the mothers/caregivers. Biesheuvel $(1987: 24)$ also recommends a multi-method strategy for transcultural research including techniques such as group discussions, interviews with small groups, participant observation, interaction between informants and interviewers and feedback discussions/debriefing. Therefore, a qualitative approach using the focus-group interview technique was chosen to complement the exploratory and descriptive nature of the research design. A structured interview guide, used by trained moderators, aided the comparison of the information obtained from the two clinics and in channeling group interaction (Morgan, 1988:56).

\section{METHODOLOGY}

\section{Focus group}

The hallmark of focus-group interviewing is: "the explicit use of the group interaction to produce data and insights that would be less accessible without the interaction found in a group" (Morgan, 1988:12). Group participation was favoured because nutritional practices, knowledge and attitudes are sensitive issues. Sharing ideas and knowledge as group members are usually more acceptable than being individually questioned on sensitive issues as people might feel they could be exposed as having little knowledge, or might feel ashamed for certain practices if asked directly. Social and cultural support were readily available in the group, therefore it was expected to encounter more spontaneous and honest participation (Denzin \& Lincoln, 1994:344-5). Figure 1 lists the sequence of steps in the design of focus-group interviews (Stewart \& Shamdasani, 1990:20).

The sequence of steps (Figure 1) will be used to discuss the methodology.

\section{Problem definition}

The formulated research question was: What are the feeding practices of children (0-3 years) in two clinics in the Moretele district in the Hammanskraal area? This implied an investigation into the nature of breast feeding and weaning practices of the mothers/ caregivers, as well as into the knowledge and attitudes of the mothers/caregivers about child nutrition.

\section{Identification of a sampling frame}

A sampling frame is a list of people that the researcher has reason to believe is representative of the larger population of interest (Stewart \& Shamdasani, $1990: 18)$. As it is inappropriate to generalize far beyond the focus-group members, the sampling frame need only be a good approximation of the population of interest (Stewart \& Shamdasani, 1990:20). This sampling frame comprised mothers/caregivers with children aged between nought to 36 months, living in two non-urban areas (Mathibestad and Makapanstad) in the Moretele district. The health care clinics were used as a base for both recruitment of the participants and conducting the research.

\section{Identification of moderator}

Two field workers/moderators of the same ethnic group were used to overcome the cultural, literacy and language problems experienced to ensure compatibility between the moderators and focus groups (Stewart \& Shamdasani, 1990:21). Separate moderators were used for each clinic exclusively, with no contact whatsoever between them.

\section{Generation and pretesting of the interview schedule}

The interview schedule is central to the focus group and necessitates appropriate design. The length of a session should be no more than one to two hours during which the focus should be maintained, also not exploring too many topics. Morgan (1988:56) advises that four to five major topics with preplanned probes under each are probably ideal. Stewart \& Shamdasani (1990:62) state that most interview schedules consist of 12 or less major topics.

The level of moderator involvement determines the design of the interview schedule. Moderator involvement lies on a continuum with high involvement being important where the moderator should control both the set of topics as well as the dynamics of the group dis- 


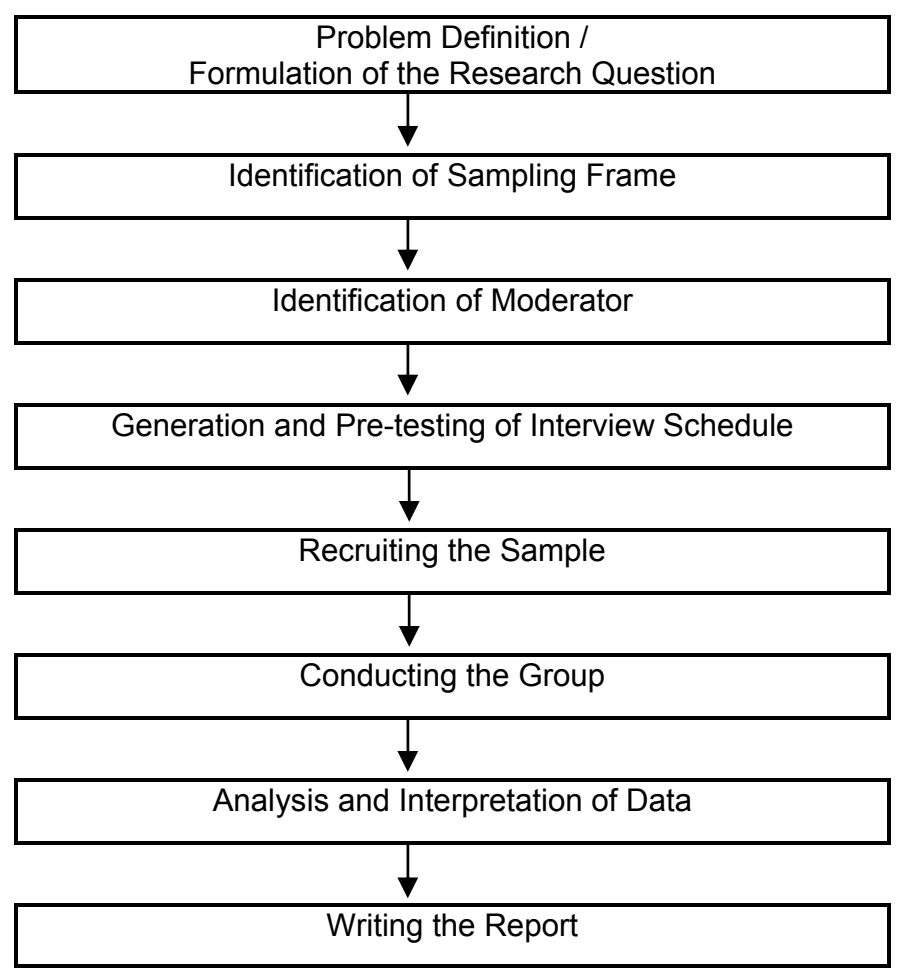

FIGURE 1: $\quad$ STEPS IN THE DESIGN AND USE OF FOCUS GROUPS (Stewart \& Shamdasani, 1990:20)

cussion, and low involvement implying a non-directive, small role in the group discussions (Morgan, 1988:48). The interview schedule was developed taking into consideration all the forementioned aspects. Due to the fact that transcultural research was undertaken and that the moderator would continuously be working from a first to a second language, it was decided to use a structured interview schedule with high moderator involvement, where the moderator had to control the set of topics as well as the dynamics of the group discussion (Morgan, 1988:48). The results from the pilot study revealed that the mothers / caregivers did not understand or interact well if a topic was put forward as a statement to be discussed. A format using structured questions in simple language, with suitable probes under each, was better understood, and also more appropriate with high moderator involvement (Morgan, 1988:49-50). Therefore, the interview schedule was constructed so that it could be followed in the same order with each of the groups. A good guide creates a natural flow of discussion on the topics and even some overlap between topics.

Six major topics on nutrition of the child to be included in the interview schedule were identified from the literature. Four topics covered the nature and justification of the feeding practices. Aspects discussed included the duration of breast feeding, the time when weaning/complementary foods were included for the first time, what the first and subsequent weaning foods were, the types of milk products that were given when breast feeding was terminated, the type of formula used, and so forth. One topic each covered the nutrition knowledge and attitudes towards nutrition respectively. Aspects that were discussed included eating patterns, types of food necessary for healthy eating, foods linked to important bodily functions, the concept of healthy food and healthy eating, money and food, traditional food preparation techniques and other customs.

\section{Recruiting the sample}

The sample was taken from mothers/caregivers and their children that visited the baby/child or immunisation clinic on Tuesday mornings. Convenience sampling was used to successfully allocate participants to one of six focus groups of mothers / caregivers (at each site) according to the age of the child. This was based on the classification of Hendricks and Badruddin (1992) that identified three overlapping periods in child nutrition including the exclusively breast fed period (0 to 12 months), the weaning period ( 3 or 4 to 24 months), and the period of the modified adult diet (24 to 36 months). This classification also identifies six phases of dietary change, which were used to categorise the children as follows:

- Focus group 1: 0 - 3 months - exclusive breast feeding (0-3 months),

- Focus group 2: 3 - 6 months - breast feeding and grains (4-6 months),

- Focus group 3: 6 - 9 months - breast feeding, grains, soft fruits and vegetables (7-9 months),

- Focus group 4: 9-12 months - breast feeding, grains, soft fruits, vegetables, meat (10-12 months), 
- Focus group 5: 12-24 months - breast feeding (supplement) and regular solid food (13-24 months),

- Focus group 6: 24-36 months - no breast feeding, only solid food (25-36 months).

Morgan (1988:46) recommends four focus groups per type to observe the range of responses on the topic. Therefore, four focus-group interviews (two per clinic) with approximately 6 mothers/caregivers per group (Morgan, 1988:47) were conducted for each of the six age groups (i.e. 24 focus groups); resulting in a total sample of 144 children. A letter of informed consent (in English / Tswana) was signed by each mother/ caregiver who agreed to participate.

\section{Conducting the focus group}

All the participants participated on two separate occasions in the research study. On the first visit, an individual interview was conducted including a biographic/ demographic questionnaire as well as other supportive quantitative data (anthropometric measurements of the child, a $24 \mathrm{~h}$-recall of the child's eating pattern and a hunger scale to evaluate food security). These results are reported elsewhere (Kruger, 1999:42-51; Kruger \& Gericke, 2003). Each mother/caregiver was scheduled to attend the focus-group interview on his/ her next scheduled clinic visit. The focus-group interviews were simultaneously conducted at each clinic during clinic hours. The researcher taught the techniques for the data collection beforehand and monitored the process at regular intervals (i.e. visiting the clinics alternatively during each research session).

The procedure entailed:

- gathering and seating the group around a table,

- making introductions between the researcher, moderator and the mothers / caregivers,

- an explanation of anonymity, value of opinions, and voluntary participation,

- explaining that the researcher did not form part of the interview process and might only be present part of the time,

- giving an overview of the general list of topics to be discussed,

- establishing the ground rules, e.g. a constant flow of responses, viewing answers as opinions, and stressing the importance of honest answers and opinions,

- indicating that refreshments would be served throughout the session by the researcher without interrupting the interview (Morgan, 1988:57-60; Stewart \& Shamdasani, 1990:87-100).

The moderator encouraged constant participation according to the interview schedule and where necessary opinions were asked directly. If the group did not respond suitably to a topic / question, the moderator used the probes on the interview schedule. Visual aids (e.g. samples of products) were used to stimulate discussion when required. A food parcel as an incentive was handed out once the individual interviews and focus-group interviews had been completed.

\section{Analysis and interpretation of data}

Qualitative research is characterized by the absence of empirical measurements with more focus on subjective evaluations (Stewart \& Shamdasani, 1990:102). Subjective evaluations were required for the description of the:

- feeding practices implemented by the mothers/ caregivers of the children,

- nutrition knowledge of the mothers/caregivers of the children, and

- attitudes of the mothers/caregivers of the children towards nutrition.

The inherent logic of qualitative research does not preclude the use of numbers, statistics, and precise quantitative measurement (Neuman, 2000:157-158). Although the purpose of qualitative research is an indepth exploration of a topic, the extent of analysis required depends largely on the aim of the research (Stewart \& Shamdasani, 1990:102). The first step in any kind of qualitative analysis is the complete transcription of all the interviews. These transcriptions should then be supplemented with the notes from the researcher and/or moderator, as well as a summary of the events as the researcher observed them (Stewart \& Shamdasani, 1990:103-104).

The data that is gathered following a qualitative approach usually comprise two types of content that need to be analysed, namely manifest and latent content:

- Manifest content is the visible, surface content, i.e. that which is obvious, like counting certain words to see if the subjects know anything about a subject. The words serve as indicators. The ease of coding and the reliability are the advantages of this method. The disadvantage however is that there is little validity in terms of the meaning of the words as such (Neuman, 2000:295).

- Latent content refers to the underlying meaning, i.e. making an overall assessment after studying the complete answer. The advantage of this method is that the underlying meaning can be determined, but at the disadvantage of low reliability and specificity (Neuman, 2000:296).

It is recommended that both types of content should be analysed in a qualitative study due to the apparent weaknesses of the two approaches. If the results from both types of content are in agreement, the final result is strengthened (Neuman, 2000:296).

The two basic approaches to analysing focus-group data are a strictly qualitative or ethnographic summary and a systematic coding via content analysis (Morgan, 1988:64). Content analysis typically produces numerical descriptions via the systematic coding of data, while an ethnographic summary provides descriptive data using direct quotations from group discussions (Morgan, 1988:64). Content analysis with categorisation of elements and exploration of their connections was implemented for this research (Miles \& Huberman, 1994:10). Pragmatical content analysis, which deals with procedures that classify signs according to 
their probable causes and effects, was selected as the most appropriate method of content analysis (Stewart \& Shamdasani, 1990:22, 107). Ethnographic summaries were used to supplement the analysed data.

During the process of content analysis, several steps need to be followed. The procedure usually entails the following: data making (unitizing, sampling, recording), data reduction, inference, analysis, validation, testing for correspondence with other methods, and testing hypotheses regarding other data. The analysis should be done with a group-for-group approach, since the group is the actual unit of analysis (Morgan, 1988:64). When an interview schedule is used in the group discussion, the topics in the guide should serve as the structure for organizing the analyses of topics. The interview schedule organizes the discussions of each group around the same set of topics and in the same order. This is a very favourable aspect during the analyses of more structured group discussions, as this allows for comparisons between the groups, as was implemented in this research (Morgan, 1988:66).

The focus-group discussions were recorded on tape. A transcription of the interview, together with a debriefing interview with the moderators (every response made was written down with the aid of the moderator who acted as translator) was done immediately after each focus-group session had been completed. This ensured that all the valuable information that the moderator could contribute was recorded (Morgan, 1988:63). An independent specialist (a dietitian from the same cultural group who was fluent in the language used during the interviews) was used at a later stage to verify the translations and quality of the data produced.

The final transcription of the data (all 26 focus groups) resulted in a voluminous data transcription document. Data reduction was partly achieved by the detailed documentation of all the transcribed interviews, and secondly by the creation of the categories for coding (Kruger \& Gericke, 2001). Miles \& Huberman $(1994: 10)$ refer to data reduction as " the process of selecting, focusing, simplifying, abstracting, and transforming data that appear in written-up field notes or transcriptions". A summary of the data reduction process for this research study is presented in Figure 2.

Data making from the transcribed data involved unitizing, sampling, and recording. Unitizing involved the formation of different units of analysis (e.g. sampling, recording and thematic units and devising data categories with each), sampling involved the selection of data to be presented (e.g. the six sampling units used for data gathering), and recording involved the coding according to the specified data categories (e.g. themes within each sampling unit) (Kruger, 1999: 148155). The researcher used the structured interview schedule as an outline to create categories for coding of data. Two coders (independent subject specialists) were used to reduce the transcribed data (responses from the various focus groups) according to the created categories and coding instructions, which were supplied by the researcher (Neuman, 2000:296; Kruger, 1999:65-66, 68,91-92).

Data inference and analysis were done according to the methodology of Krippendorf (1980:33-84) and Stewart \& Shamdasani (1990:105-113). Content was analysed in terms of manifest as well as latent content. Many responses to questions/probes could be classified as manifest content. These included countable objects or concepts such as the age of the children, types of teachers or informants, types of actions, frequencies, volumes, utensils, foods, etc. The latent content concerns the underlying meaning. It consisted of the reasons given by the mothers/caregivers for the practices or actions they followed, their beliefs concerning nutrition knowledge, their reasons for the nutrition-related attitudes that they had and how these might have influenced their practices. The analysis was organized in terms of the different topics included in the interview schedule (Morgan, 1988:66). These six topics (sampling units) also delineated the context within which the data reduction was done and presented, and each was reported/discussed separately. Examples from the various data making categories for the different sampling units are summarized in Table

Within each sampling unit (SU), all the recorded data were first categorised in recording units (RU's). These consisted of physical units (e.g. types of milk), referential units (e.g. reasons for choices of milk), and thematic units (e.g. breast feeding practices) that were identified and reported. Themes that were revealed from interesting discussions were classified as thematic units. These were discussed in detail and were linked to the various PU's and RU's, e.g. preparation technique for bottle feeding. The recorded data revealed new categories, contexts and themes and subsequently the reports were compiled according to the context units in each SU, e.g. milk drinking practices under the topic of weaning. All of these discussions were strengthened by direct quotes from the respondents.

\section{Writing the report}

To justify any inferences from the data, some knowledge or empirical evidence about the connections between data and what is to be inferred from them is essential. This knowledge serves to place data in a suitable context (Krippendorf, 1980:55, 80-84). The most common form of representation of data is by means of frequencies - both absolute and relative frequencies, such as numbers and percentages (Krippendorf, 1980:189). To effectively draw conclusions and take action, it is necessary to have a data display which is an organized, compressed assembly of information. Well-constructed data displays (graphs, matrixes, charts, etc.) are a major avenue to valid qualitative analysis (Miles \& Huberman, 1994:11). In this research tables were used to display the data in the reduced form and on a comparative basis between clinics and age-categories. Simultaneous discussion referring to each question / probe in the interview schedule reflecting on frequencies of 


\begin{tabular}{|c|c|c|c|c|c|c|c|}
\hline \multicolumn{2}{|c|}{ 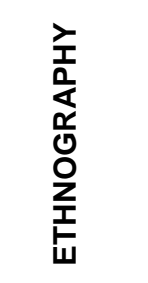 } & 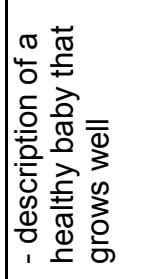 & 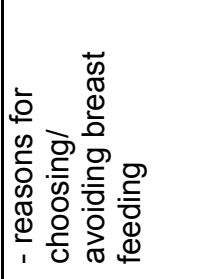 & 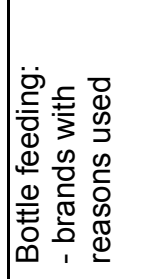 & 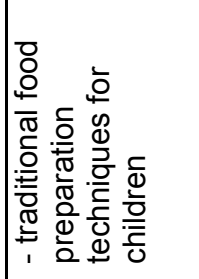 & 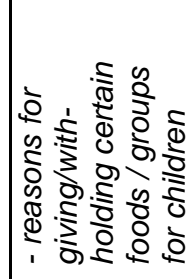 & 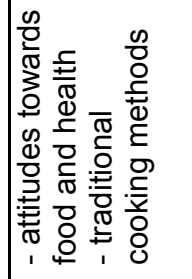 \\
\hline \multicolumn{2}{|c|}{ 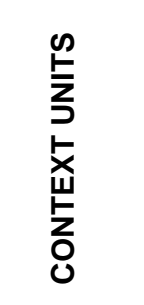 } & 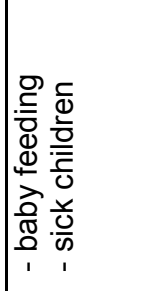 & 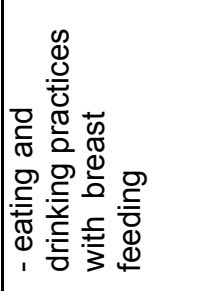 & 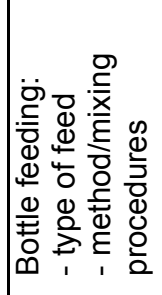 & 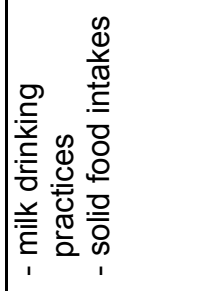 & 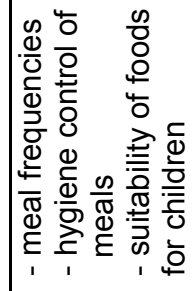 & 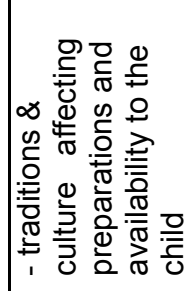 \\
\hline \multirow{3}{*}{ 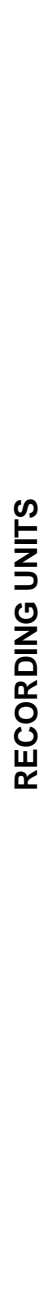 } & 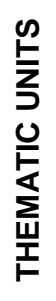 & 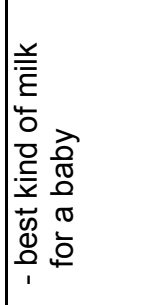 & 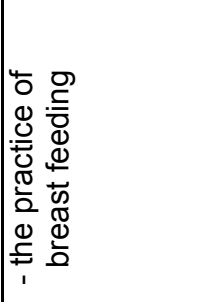 & 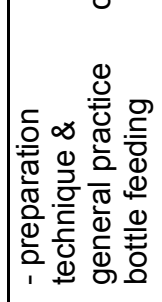 & 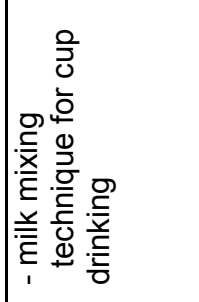 & 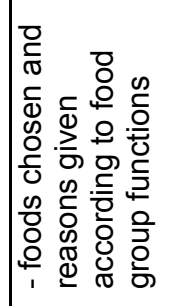 & 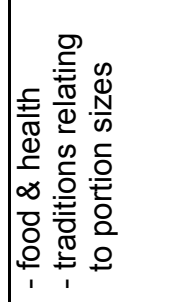 \\
\hline & 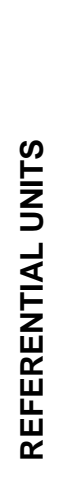 & 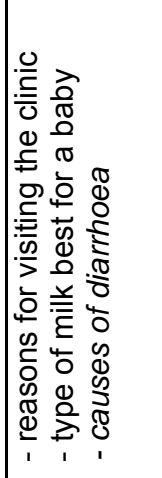 & 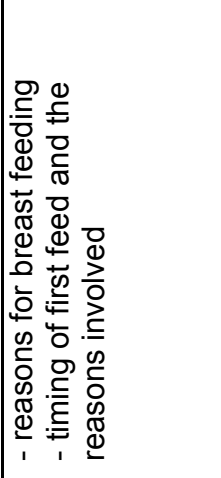 & 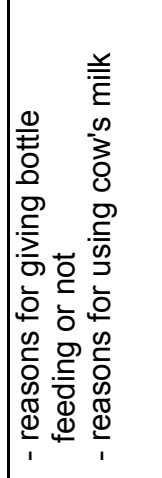 & 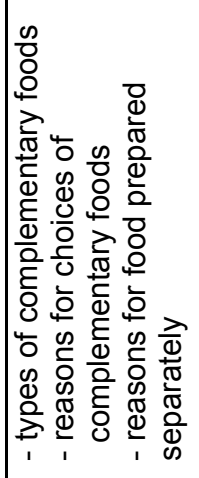 & 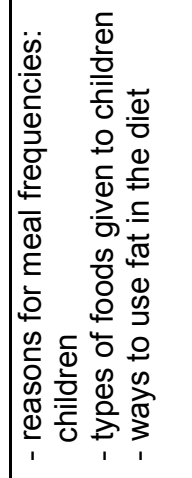 & 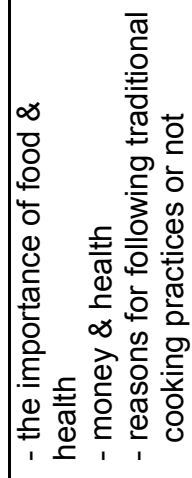 \\
\hline & 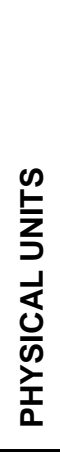 & 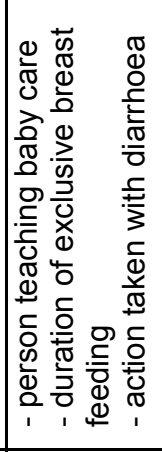 & 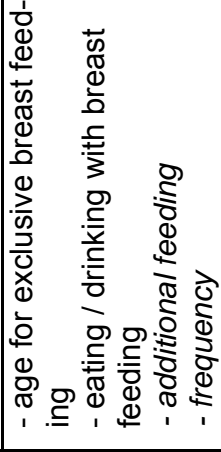 & 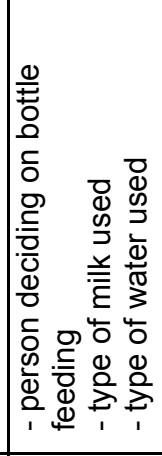 & 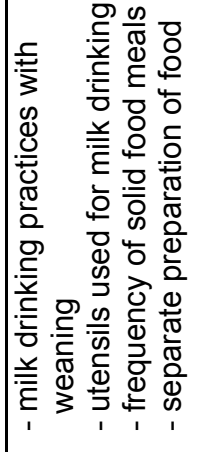 & 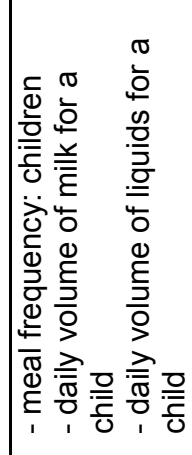 & \\
\hline \multicolumn{2}{|c|}{ 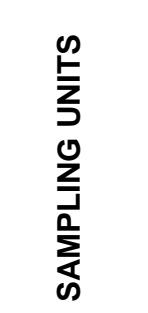 } & 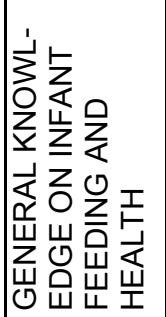 & 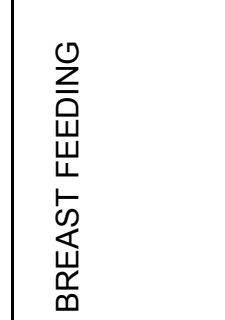 & 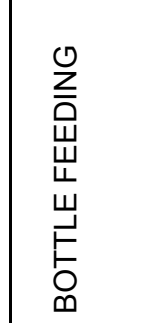 & 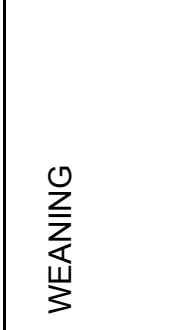 & 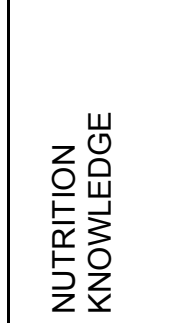 & 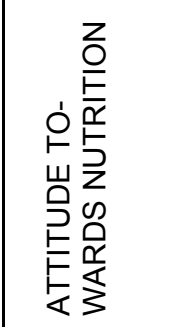 \\
\hline
\end{tabular}




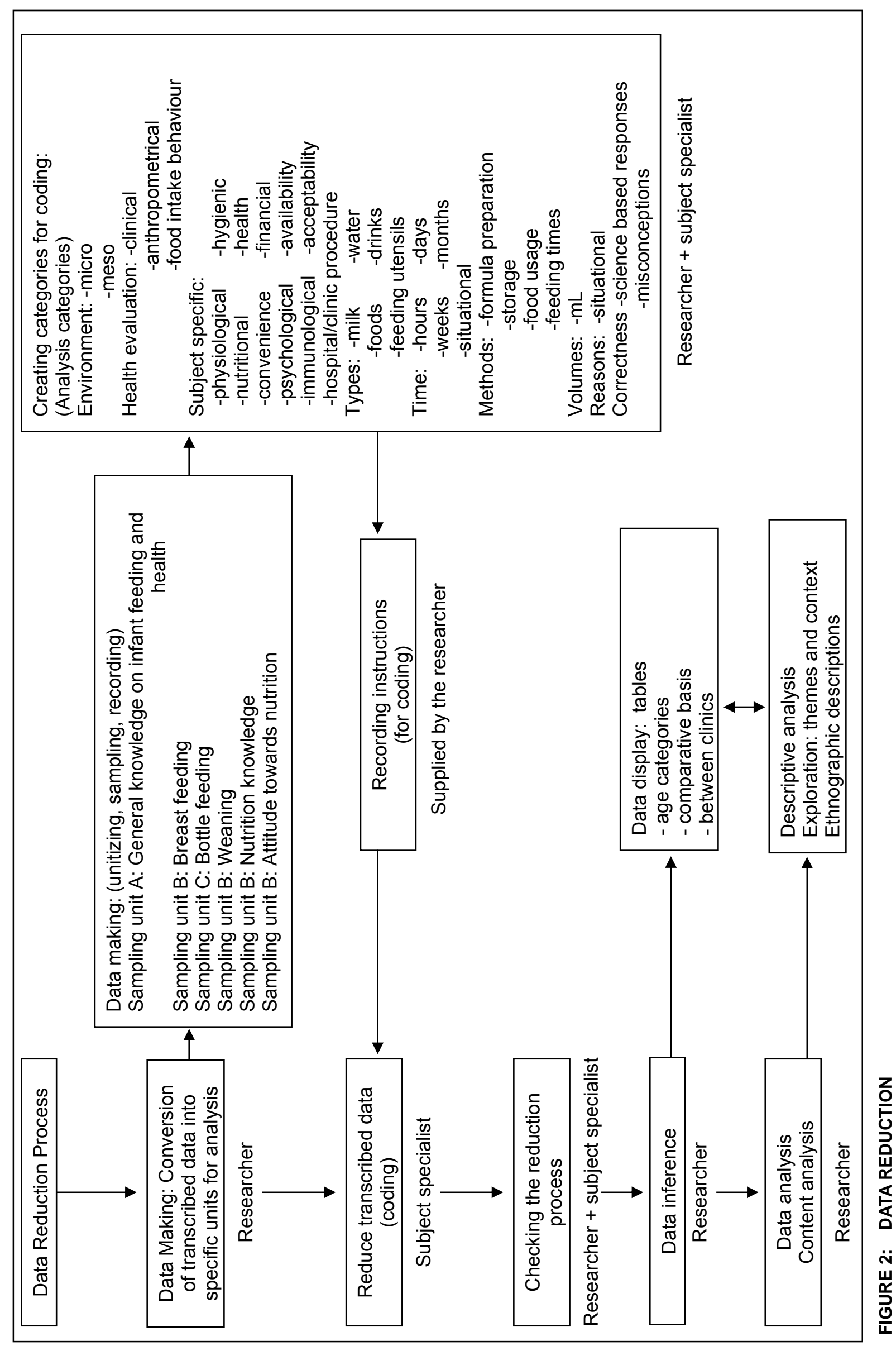




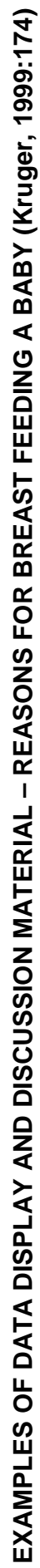

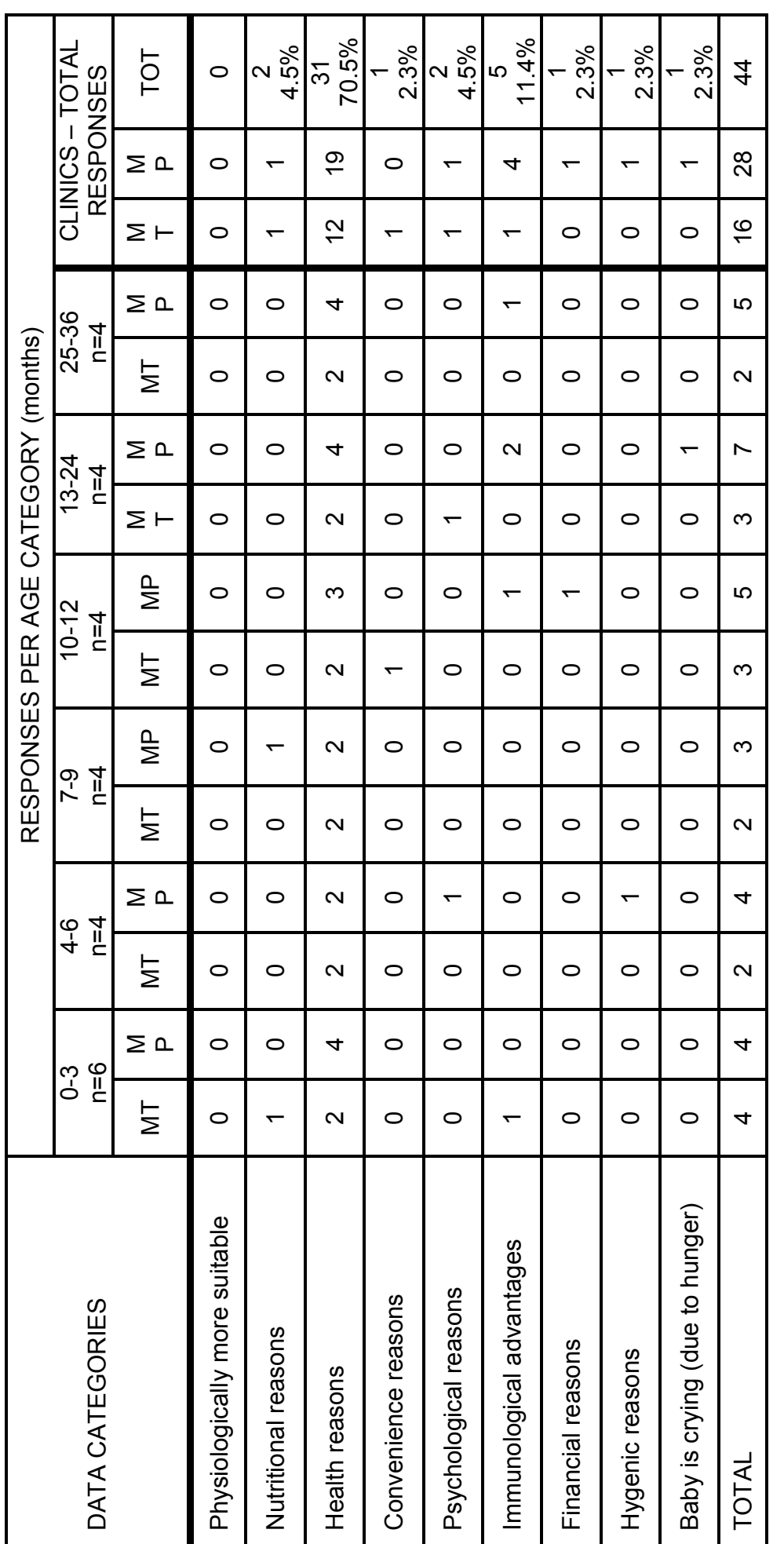

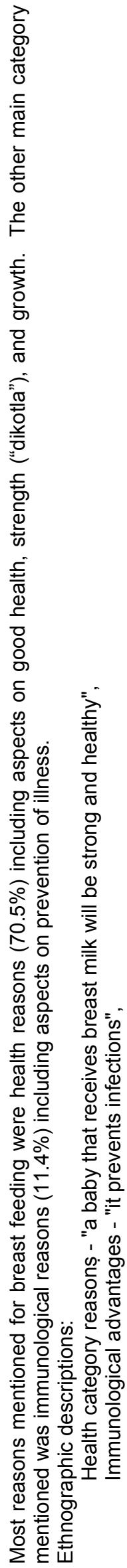


responses from the two clinics (Makapanstad and Mathibestad) was done (Kruger \& Gericke, 2001). Descriptive analysis by means of ethnographic summaries (from the group discussions), complemented with direct quotes to verify the data (Morgan, 1988:70), supported the reporting of the content analysis (Kruger \& Gericke, 2001). An example of one of the data displays is presented in Table 2 (Kruger, 1999:174).

\section{Validity and reliability (trustworthiness) of the methodology used}

Within the qualitative research paradigm the same reliability and validity issues are of importance as in all scientific measurements. Perfect reliability and validity are the ideal, but difficult to attain. Reliability deals with the dependability and consistency of an indicator, while validity (credibility) is concerned with the actual meaning of an indicator (Neuman, 2000:164-173).

The following measures were implemented to improve the reliability of the research approach:

- clear, well-defined conceptual definitions were used,

- all the measuring instruments were pretested for comprehensibility, applicability and clarity,

- the two moderators evaluated the instruments with reference to the level of difficulty and the understandability,

- he focus-group interview schedule was tested twice beforehand,

- one specific moderator only from the same ethnical group and who was living in the same area, was used per clinic in order to achieve a high level of trust with the mothers/caregivers,

- a separate moderator was used at each clinic, with no contact whatsoever between them, thus reducing the possibility for misinterpretation and prejudice,

- the moderators were trained thoroughly about the research procedures,

- confidentiality was ensured by means of a formal consent form,

- the researcher never conveyed her own opinion, attitudes or beliefs to the mothers/caregivers or to the moderators/interviewers,

- leading questions were avoided,

- during the content-analysis phase, two independent coders (subject specialists) were used to record data into the relevant data categories,

- the data categories created for the recording of the data were clearly specified with clear instructions as to the specific information required to ensure the correct construct being coded (Neuman, 2000:164-173).

The following measures were implemented to improve the validity in this research approach:

- purposefulness was achieved through a thorough review of the literature concerning the causes and effects of malnutrition, the feeding practices applied to infants and small children, as well as the knowledge component involved and the attitudes towards these issues,

- concepts were defined explicitly in terms of their meaning for this research to ensure explicitness and to prevent any misunderstanding.

- specialists in the field of nutrition approved all the instruments used,

- selected instruments incorporated all aspects of the concepts being studied, aiming at depicting them in their complexity,

- multiple indicators were introduced for evaluating the different practices by means of different questions / probes concerning similar content in the different sampling units to ensure confirmability,

- an independent subject specialist was consulted to verify the translations and quality of the data produced by the two moderators (Neuman, 2000:164-173).

\section{CONCLUSION}

A qualitative research approach should be considered when in-depth explorative and/or descriptive research on eating behaviour (practices, knowledge, attitudes) is planned. Although it is time consuming, it produces rich and meaningful data that in itself serves to improve understanding of specific communities and their nutrition practices and knowledge.

\section{LIST OF REFERENCES}

BIESHEUVEL, S. 1987 Cross-cultural psychology: Its relevance to South Africa. In: Mauer KF, Retief Al. Psychology in context: Cross-cultural research trends in South Africa. Pretoria. HSRC.

DENZIN, NK \& LINCOLN, YS. (eds). 1994. Handbook of qualitative research. London. Sage.

GIACOMINI, MK. 2001. The rocky road: qualitative research as evidence. Evidence Based Medicine 6:45.

HENDRICKS, KM \& BADRUDDIN, SH. 1992. Weaning recommendations: The scientific basis. Nutrition Reviews 50(5):125-133.

KIBEL, MA \& WAGSTAFF, LA (eds). 1995. Child health for all. A manual for southern Africa. 2nd ed. Cape Town. Oxford University Press.

KRIPPENDORF, K. 1980. Content analysis. An introduction to its methodology. The Sage COMMTEXT Series: volume 5. London. Sage Publications.

KRUGER, R \& GERICKE, GJ. 2003. A qualitative exploration of rural feeding and weaning practices, knowledge and attitudes on nutrition. Public Health Nutrition 6(2):217-223.

KRUGER, R \& GERICKE, GJ. 2001. Breast feeding practices of mothers with children (aged 0-36 months) in a rural area of South Africa. A qualitative approach. Journal of Family Ecology and Consumer Sciences 29:60-71.

KRUGER, R. 1999. Feeding practices and nutritional status of children (aged 0 to 3 years) in two clinics in the Moretele district. M Dietetics dissertation. University of Pretoria.

MARTORELL, R. 1993. Enhancing human potential in 
Guatemalan adults through improved nutrition in early childhood. Nutrition Today (January/February):6-13. MILES, MB \& HUBERMAN, AM. 1994. Qualitative data analysis. London. Sage Publications.

MORGAN, DL. 1988. Focus groups as qualitative research. Qualitative research methods series. Volume 16. London. Sage.

NEUMAN, WL. 2000. Social research methods: Qualitative and quantitative approaches. $4^{\text {th }}$ ed. Boston. Allyn \& Bacon.

NG'ANDU, NH \& WATTS, TEE. 1990. Child growth and duration of breast feeding in urban Zambia. Journal of Epidemiology and Community Health 44:281285.

OCLOO, E. 1993. Chronic undernutrition and the young. Proceedings of the Nutrition Society 52:11-17. PATEL, DN \& PETTIFOR, JM. 1992. Malnutrition in
South Africa. The SA Journal of Food Science and Nutrition 4(2):22-23.

PRENTICE, A. 1991. Breast feeding and the older infant. Acta Paediatrica Scandinavia Supplement 374:78-88.

SCHOEMAN, JB. 1988. Essays on cultural psychology. Pretoria. Westford Hospital.

STEWART, DW \& SHAMDASANI, PN. 1990. Focus groups. Theory and practice. Applied Social Research Methods Series. Volume 20. London. Sage.

STEYN, NP, BADENHORST, CJ, NEL, JH \& LADZANI, R. 1993. Breast-feeding and weaning practices of Pedi mothers and the dietary intakes of their preschool children. The SA Journal of Food Science and Nutrition 5(1):10-13.

TERRY, RD. 1993. Introductory community nutrition. Dubuque. Wm. C. Brown. 